\title{
COMPARATIVE RADIOGRAPHIC ANALYSIS OF THE RESULTS OF TREATMENT OF HALLUX VALGUS DEFORMITY ACCORDING TO MITCHELL AND KELLER OPERATIVE METHODS
}

\author{
Georgieva Daniela, Poposka Anastasika, Bozinovski Zoran, Samardziski Milan, \\ Dzoleva-Tolevska Roza, Nanceva Jasminka
}

PHI University Clinic for Orthopedic Surgery, Clinical Center Mother Teresa - Skopje, Medical faculty, Ss. Cyril and Methodius University, Skopje, Republic of Macedonia

Primljen/Received 25. 01. 2016. god.

Abstract: Introduction: Hallux valgus represents a complex progressive deformity of the front part of the foot, with the most distinguished malformation as lateral deviation of the toe. Radiography is extremely important in the decision of the surgical procedure for the best correction of this deformity. Aim: The aim of this work is to show the significance of radiographic examinations in operated patients with Hallux Valgus deformityaccording to Mitchell and Keller techniques. Material and methods: The study included 70 patients having hallux valgus deformity of the foot, and they were divided to two groups. The patients were grouped according their sex, age, the degree of deformity (moderate or severe degree of deformity) and according to radiographic findings. The first group (Group 1) was composed of 35 patients who were treated by osteotomy of the I metatarsal bone according to Mitchell, while the second group (Group 2) was also composed of 35 patients who were treated by resectional arthroplasty according to Keller. Radiographic examinations (Method of Hardy and Clapham, Piggott classification, presence and absence of the secondary arthritic and reactive changes of the first metatarsophalangeal joint) were analyzed comparatively during the evaluation. The analyses of the radiographic results were performed pre-operatively and post-operatively for the two groups. Results: According to their sex, the patients were 5 men and 65 women. The average age of the patients in group 1 was 42 years, while for group 2 it was 56 years. There is no significant difference $(\mathrm{p}>0.05)$ in the patients of the two groups concerning the pre-operative mean dimension values of the I metatarsophalangeal angle and I intermetatarsal angle. However, the radiographic analysis of the same angles in both gro-
Prihvaćen/Accepted 28. 02. 2016. god.

ups, one year post-operatively, showed a high statistically significant difference $(\mathrm{p}<0.001)$. The patients operated by Mitchell's technique, according to Piggott classification, have deviation significantly more often on the I metatarsophalangeal joint of $51.43 \%$ as a result of their hallux valgus deformity. Significantly more often, there is a subluxation of $77.14 \%$ on the I metatarsophalangeal joint in the patients treated by Keller's technique. The radiographic analysis of the I metatarsophalangeal joint (presence and absence of the secondary arthritic and reactive changes) in both groups, pre-operatively $(\mathrm{p}<0.01)$ and one year post-operatively $(\mathrm{p}<0.001)$, showed a high statistically significant difference.

Conclusion: Radiographic analyses were of enormous benefit as in the choice of the decision on the type of the operative procedure and also for the evaluation of the postoperative results.

Key words: radiographic analysis, Mitchell, Keller, hallux valgus.

\section{INTRODUCTION}

The first thorough description of hallux valgus deformity was published in 1871 by Carl Hueter. Hallux valgus deformity characterized with valgus position of the big toe, enlarged of the I intermetatarsal angle, appearance of pseudoegsostosis or bursitis in the area of the medial side of the head of the I metatarsal bone, as well as with an inside rotation of the big toe in more severe cases.

Since no muscles insert into the metatarsal head, it is vulnerable to extrinsic factors. Furthermore, the I metatarsophalangeal joint plays a major role in the transmission of body weight during locomotion, and if 
there is abnormal stress placed on the joint it may become deformed. Static deformities such as hallux valgus have a tendency to affect this joint and may require surgical intervention $(1,2)$.

A physical examination demonstrates that the affected joint is tender. Motion of the joint often causes discomfort. Bony proliferation around the margin of the affected joint can be palpated and is frequently visible. On the basis of radiographic analysis of the foot with hallux valgus gets systematic tracking and adequate treatment of this deformity. A radiographic examination demonstrates a grade of deformity according to values of I metatarsophalangeal and first intermetatarsal angle, evaluation of the condition of the first metatarsophalangeal joint and secondary arthritic and reactive changes in the same joint $(3,4,5,6)$.

The treatment of hallux valgus is surgical. More than 150 surgical procedures have been describes for the correction of this deformity. The numerous operative procedures and modifications point to the fact that none of them can make a correction on every hallux valgus deformity. The essence of these surgical procedures is to correct the deformity, to make an effort to eliminate the anatomic potential for the origination of the deformity, and to create a normal position, direction and physiologically antagonistic function of the muscles which are not balanced $(7,8,9)$. The main parameters in the selection of the surgical procedure are by the type of deformity, the degree of deformity, clinical, radiographic findings, patient age, comorbidities and the expectations of patients from the surgery itself. In this paper, emphasis is set on comparative preoperative and postoperative radiographic analysis in patients operated according to the methods of Mitchell and Keller.

\section{AIM}

The aim of this work is to show the importance of radiographic examinations in preoperative and postoperative period in patients with hallux valgus deformity operated by the methods of Mitchell and Keller.

\section{MATERIAL AND METHODS}

The study was carried out at the University Orthopaedic Surgery Clinic, Faculty of Medicine in Skopje, in the period from 2008 to 2012 year. The material for the research consisted of 70 patients having hallux valgus deformity. The patients were divided to two groups of 35 patients each. They were treated by operative procedures according to the methods of Mitchell (first group), and of Keller (second group). The study included patients with only static hallux valgus deformity. Of the study were excluded young patients up to 20 years of age, congenital, inflammatory and post-traumatic hallux valgus deformity.
The patients were grouped according to their sex, age (in 2 groups: from 20 to 50 and over 50 years of age), the degree of deformity (moderate or severe degree of deformity), and according to the clinical and radiographic findings. Grouping of patients was done by orthopedic surgeons who be conducted by both operational intervention. The operative procedures in both groups were performed under regional spinal anesthesia.

Radiographic examinations were done by the method of Hardy and Clapham (the dimensions of the I metatarsophalangeal and the I intermetatarsal angle are determined by this method), Piggott method (according to this method the I metatarsophalangeal joint can be congruent, in deviation, and with subluxation). A radiographic examination in the first metatarsophalangeal joint demonstrated sclerotic joint margins, proliferative bone about the periphery of the joint (osteophytes), and subchondral cyst formation. In accordance with the radiographic findings, in our study, patients with moderate degree of deformity were selected in the first, Mitchell group, while patients with severe degree of deformity were included in the second, Keller group.

Radiographic examinations were done pre-operatively and post-operatively. Radiographic measurements were made strictly from within orthopedic surgeons who conducted the appropriate surgical intervention.

For statistical analysis of data obtained in the study was made based in statistical program SPSS 13.0 for Windows. Moreover, during the computer analysis were used the following statistical methodologies: t-test for independent samples, Kolmogorov-Smirnov two sample test, and Chi-square Pearson test with and without correction.

\section{RESULTS}

According to sex, the first group consisted of 3 $(8.57 \%)$ male patients and $32(91.43 \%)$ female patients, while the second group consisted of $2(5.71 \%)$ males and 33 (94.29\%) female patients. The difference between the two groups is statistically highly significant $(\mathrm{p}<0.001)$.

The average age of the patients in group 1 was $41.94 \pm 16.5$ years, while for group 2 it was $56.29 \pm 12.5$ years. The difference in the mean age between the two groups is statistically highly significant $(\mathrm{p}<0.001)$.

An average dimension of the I metatarsophalangeal angle of $40.31 \pm 7.6$ degrees was measured in the group of patients treated by the method of Mitchell, before the operation, and it is not significantly greater $(\mathrm{p}$ $>0.05$ ) than the average dimension of the same angle in the group of patients treated by the method of Keller, 
where its value is $37.49 \pm 9.7$ degrees (Table 1). The dimension of the I metatarsophalangeal angle in all patients was measured post-operatively during the control examinations, namely 3 months and 1 year after the intervention. The average dimension of the I metatarsophalangeal angle in the patients operated by the method of Mitchell after 3 months was $16.97 \pm 3.8$ degrees, after operation while in the patients operated by the method of Keller this average dimension was smaller and was $15.0 \pm 1.7$ degrees. This difference tested by the $t$ test for independent samples was statistically high significant ( $\mathrm{p}$ $<0.01$ ). During the second control examination, 1 year post-operatively, average dimension of the 1st metatarsophalangeal angle in the patients of the first group was $18.66 \pm 4.0$ and $15.83 \pm 1.9$ degrees in the patients of the second group. This difference was statistically high significant $(\mathrm{p}<0.001)$, (Table 2).

There is a non-significant difference in the pre-operative average values in the dimensions of the 1 st intermetatarsal angle in the patients of both groups. Its value was $15.26 \pm 3.9$ degrees in the patients treated by the method of Mitchell and $14.97 \pm 4.0$ degrees in the patients treated by the method of Keller (Table 1). The average dimension of the 1 st intermetatarsal angle, 3 months after the operation was $10.83 \pm 2.4$ degrees (Mitchell), and it is significantly less $(p<0.001)$ than the average dimension of this angle treated by the method of Keller, which was $14.97 \pm 4.0$ degrees. This statistically signifi- cant difference $(\mathrm{p}<0.001)$ in the average dimension of the Iintermetatarsal angle between the two groups was confirmed 1 year after the operation, too (Table 3 ).

The patients operated by Mitchell's technique, according to Piggott classification, have deviation significantly more often on the 1 st metatarsophalangeal joint of $51.43 \%$ as a result of their hallux valgus deformity. Significantly more often, there is a subluxation of $77.14 \%$ on the 1 st metatarsophalangeal joint in the patients treated by Keller's technique (Table 4). Piggot classification was useful for Mitchell group (Table 5), but it was not possible to use post-operatively in patients from the second group since it was made resection arthroplasty by the method of Keller.

The secondary arthritic and reactive changes in the area of 1st metatarsophalangeal joint were registered in $6(17.1 \%)$ patients operated by Mitchell's technique, and in $30(85.7 \%)$ patients operated by Keller' procedure. The tested difference for the presence and absence of the secondary arthritic and reactive changes in the patients treated by the two different operative techniques was verified as statistically highly significant $(\mathrm{p}<0.001)$. During the second follow-up examination, 1 year post-operatively, the secondary arthritic and reactive changes in the patients in the first group was $7(20 \%)$ and $31(88.6 \%)$ in the patients in the second group. This difference was statistically highly significant $(\mathrm{p}<0.001)$.

Table 1. I metatarsophalangeal/intermetatarsal angle-pre-operatively

\begin{tabular}{|l|c|c|c|c|c|c|}
\hline \multicolumn{1}{|c|}{$\begin{array}{c}\text { BEFORE } \\
\text { OPERATION }\end{array}$} & $\begin{array}{c}\text { Mean } \\
\text { MITCHELL }\end{array}$ & $\begin{array}{c}\text { Standard } \\
\text { deviationMITCHELL }\end{array}$ & $\begin{array}{c}\text { Mean } \\
\text { KELLER }\end{array}$ & $\begin{array}{c}\text { Standard } \\
\text { deviationKELLER }\end{array}$ & t-value & $\mathbf{p}$ \\
\hline $\begin{array}{l}\text { I metatarsophalangeal } \\
\text { angle }\end{array}$ & 40.31 & 7.6 & 37.49 & 9.7 & 1.36 & 0.18 \\
\hline I intermetatarsal angle & 15.26 & 3.9 & 14.97 & 4.0 & 0.3 & 0.76 \\
\hline
\end{tabular}

Table 2. I metatarsophalangeal angle - 3 months/1 year post-operatively

\begin{tabular}{|l|c|c|c|c|c|c|}
\hline \multicolumn{1}{|c|}{$\begin{array}{c}\text { AFTER } \\
\text { OPERATION }\end{array}$} & $\begin{array}{c}\text { Mean } \\
\text { MITCHELL }\end{array}$ & $\begin{array}{c}\text { Standard } \\
\text { deviationMITCHELL }\end{array}$ & $\begin{array}{c}\text { Mean } \\
\text { KELLER }\end{array}$ & $\begin{array}{c}\text { Standard } \\
\text { deviationKELLER }\end{array}$ & t-value & $\mathbf{p}$ \\
\hline $\begin{array}{l}\text { I metatarsophalangeal } \\
\text { angle - 3 months }\end{array}$ & 16.97 & 3.78 & 15.0 & 1.66 & 2.82 & 0.006 \\
\hline $\begin{array}{l}\text { I metatarsophalangeal } \\
\text { angle - } 1 \text { year }\end{array}$ & 18.66 & 3.99 & 15.83 & 1.93 & 3.77 & 0.00034 \\
\hline
\end{tabular}

Table 3. I intermetatarsal angle - 3 months/1 year post-operatively

\begin{tabular}{|l|c|c|c|c|c|c|}
\hline \multicolumn{1}{|c|}{$\begin{array}{c}\text { AFTER } \\
\text { OPERATION }\end{array}$} & $\begin{array}{c}\text { Mean } \\
\text { MITCHELL }\end{array}$ & $\begin{array}{c}\text { Standard } \\
\text { deviationMITCHELL }\end{array}$ & $\begin{array}{c}\text { Mean } \\
\text { KELLER }\end{array}$ & $\begin{array}{c}\text { Standard } \\
\text { deviationKELLER }\end{array}$ & t-value & p \\
\hline $\begin{array}{l}\text { I intermetatarsal angle }- \\
\text { 3 months }\end{array}$ & 10.83 & 2.36 & 14.97 & 4.0 & -5.27 & 0.000001 \\
\hline $\begin{array}{l}\text { I intermetatarsal angle }- \\
\text { 1 year }\end{array}$ & 11.26 & 2.58 & 14.97 & 4.0 & -4.61 & 0.000018 \\
\hline
\end{tabular}


Table 4. Condition of the I metatarsophalangeal joint between both groups - pre-operatively

\begin{tabular}{|l|c|c|c|c|}
\hline \multirow{2}{*}{$\begin{array}{c}\text { Condition of the } \\
\text { Imetatarsophalangeal joint }\end{array}$} & \multicolumn{2}{c|}{ MITCHELL - group 1 } & \multicolumn{2}{c|}{ KELLER - group 2 } \\
\cline { 2 - 5 } & Nomber & $\%$ & Nomber & $\%$ \\
\hline Congruent & 2 & 5.71 & 1 & 2.86 \\
\hline In deviation & 18 & 51.43 & 6 & 17.14 \\
\hline With subluxation & 15 & 42.86 & 27 & 77.14 \\
\hline Luxation & 0 & 0 & 1 & 2.86 \\
\hline Summary & 35 & 100 & 35 & 100 \\
\hline
\end{tabular}

Kolmogorov-Smirnov Dmax $=-0.38, \mathrm{p}<0.025$

Table 5.Condition of the I metatarsophalangeal joint-pre-operatively/post-operatively (Group 1)

\begin{tabular}{|l|c|c|c|c|}
\hline \multirow{2}{*}{$\begin{array}{c}\text { Condition of the } \\
\text { Imetatarsophalangeal joint } \\
\text { in Mitchell group }\end{array}$} & \multicolumn{2}{|c|}{ Pre-operatively } & \multicolumn{2}{c|}{ Post-operatively } \\
\cline { 2 - 5 } & Nomber & $\%$ & Nomber & $\%$ \\
\hline Congruent & 2 & 5.71 & 30 & 85.71 \\
\hline In deviation & 18 & 51.43 & 5 & 14.29 \\
\hline With subluxation & 15 & 42.86 & 0 & 0 \\
\hline Summary & 35 & 100 & 35 & 100 \\
\hline & & & & \\
\hline
\end{tabular}

\section{DISCUSSION}

Patients with hallux valgus deformity of our region were included in this prospective study, the first of its kind in the Republic of Macedonia. From numerous surgical techniques attention about resolving this deformity in this study were processed essentially two completely different procedures. An important place is given to this deformity in the world literature as a complex orthopedic problem. It is a subject of the numerous clinical studies during the past decades. This study resulted from the fact that this deformity is insufficiently elaborated in our environment, and it will contribute either in the orthopedic theory or orthopedic practice.

Hallux valgus is the most frequent deformity of the foot. It presents a complex and progressive deformity which affects the front part of the foot, where the most emphatic change is the lateral deviation of the big toe. Concerning the type of deformity, the static one was the most prevalent in our study, but also it is represented in all scientific studies for this deformity $(7,8,9)$.

The world literature data show more frequent incidence of this deformity in women compared to men, which is the case in our study, too $(1,2,3)$. The mean age of the patients is 41 and 56 years of age, according to Mitchell and Keller respectively.

In more studies and papers like Joseph TN, Kitson $\mathrm{K}$, Chong N, with collaborators, and many others, the accent was put on the importance of radiographic analysis in the surgical treatment ofhallux valgus deformity
$(8,9,10)$. Based on the radiographic variables, we can make correct evaluation of the type and degree of the deformity. The angles and distances are manifested variables for studying the deformity degree. Radiographic findings should always be in correlation to clinical findings. Based on the clinical-radiographic analysis of the foot with hallux valgus, systematic following and adequate treatment of this deformity is enabled $(11,12,13,14,15)$. Our study, too, showed the usefulness of the classification according to Hardy and Clapham for the determination of the hallux valgus deformity degree in respect to the dimension of I metatarsophalangeal angle and I intermetatarsal angle pre- and post-operatively. The mean dimension of I metatarsophalangeal angle and I intermetatarsal angle post-operatively, in both groups, was shown as the significantly high $(p<0.001)$. This study showed that the operational procedure according to Mitchell reduces the value of I metatarsophalangeal angle and I intermetatarsal angle to normal values, while operating procedure Keller does not correct metatarsus primus varus, followed by post-operative I intermetatarsal angle remains unchanged values, while I metatarsophalangeal angle is reduced to normal.

Ferrari J.underlines the importance of congruence of I metatarsophalangeal joint (15). In our study application of Piggott classification showed as very important one in the choice of corresponding surgical procedure in the treatment of hallux valgus deformity. Preoperative respondents operated by Mitchell technique had signifi- 
cantly more often deviated I metatarsophalangeal joint, while subjects treated by Keller technique significantly more common are diagnosed subluxation. Postoperatively the method of Mitchell, congruent I metatarsophalangeal joint register with a majority of respondents in this group $85.7 \%$, while the remaining $14.3 \%$ registered deviation.Postoperatively the respondents operated by the method of Keller was not possible to use this classification due to performed resection of the proximal half of the proximal phalanx of the thumb.

The changed ratios of the foot can be determined by the help of radiography, and in the later stages secondary arthritic and reactive changes can be also determined $(3,5,6,12,13)$. The secondary arthritic and reactive changes (osteophytes, subchondral sclerosisand degenerative cysts) in the area of I metatarso-phalangeal joint were not a frequent occurrence in the patients treated by the method of Mitchell, neither pre-operatively nor post-operatively. They were registered in 6 patients pre-operatively and in 7 patients after the intervention. Secondary arthritic and reactive changes in the area of I metatarso-phalangeal joint were diagnosed pre-operatively in $30(85.7 \%)$ patients in the group surgically treated by the method of Keller, and that was the case with 31 patients post-operatively. Tested the difference between respondents in both groups with or without secondary arthritic changes postoperatively showed highly statistically significant $(\mathrm{p}<0.001)$, as a result of significantly more often diagnose these changes in the group of subjects treated with the method of Keller. In our study, as well as in the world literature, the operative method by Keller showed as "golden standard" for the patients having arthritic changes.

Numerous surgical procedures for correction of this deformity are described. They can be simple abla- tions with capsulographies up to complex operations such as arthrodesis, transfer of tendons, resection arthroplasty and different osteotomies of the I metatarsal bone. The operative procedure must protect the integrity of the anatomic structure of the joint $(1,16,17)$. Another important deciding factor is the presence or absence of arthrosis in the joint. Especially important as an indication of a surgical procedure is always to have in mind what are the patient's expectations from the operation $(3,17,18)$.

\section{CONCLUSION}

Radiographic analyses are of special importance in order to make a final decision for the type of operative treatment. Our study, at the same time showed that radiographic analysisis very useful for an excellent evaluation of preoperative, postoperative period and further controls of the patients.

In this study, the operative technique according to Mitchell showed to be an effective procedure for hallux valgus and metatarsus primus varus in young and middle-aged patients. The resectional arthroplasty according to Keller's method is a good procedure for correction of hallux valgus deformity in older patients having arthrotic changes. The results of this research have major implications for the systematic monitoring and planning of activities for adequate surgical treatment of patients with hallux valgusdeformity, but also making its own contribution to contemporary orthopedic practice and science.

\section{Conflict of interest}

The authors declare that there are no conflicts of interest.

\title{
Sažetak
}

\section{KOMPARATIVNA ANALIZA RADIOGRAFSKIH REZULTATA NAKON HIRURŠKIH PROCEDURA PO MITCHELL-u i KELLER-u U LEČENJU HALLUX VALGUS DEFORMACIJE}

\author{
Georgieva Daniela, Poposka Anastasika, Bozinovski Zoran, Samardziski Milan, \\ Dzoleva-Tolevska Roza, Nanceva Jasminka \\ PHI University Clinic for Orthopedic Surgery, Clinical Center Mother Teresa - Skopje, Medical faculty, \\ Ss. Cyril and Methodius University, Skopje, Republic of Macedonia
}

Uvod: Hallux valgus predstavlja kompleksan progresivan deformitet stopala, sa najviše izraženom lateralnom devijacijom palca. Radiografija zauzima izuzetno važno mesto u donošenju odluke o tipu hirurškog zahvata, koji je najbolji za korekciju ovog deformiteta.
Cilj: Cilj ovog rada bio je da se pokaže značaj radiografskog ispitivanja u operisanih pacijenata sa hallux valgusom, po Mitchell i Keller tehnikama.

Materijal i metode: U studiju je uključeno 70 pacijenata sa hallux valgus deformacijom stopala, koji su 
bili podeljeni u dve grupe. Pacijenti su bili podeljeni prema polu, uzrastu, stepenu deformiteta (umereno do ozbiljnog stepena deformiteta) i prema radiološkim nalazima. Prvu grupu (Grupa 1) je činilo 35 pacijenata koji su bili lečeni osteotomijom I metatarzalne kosti, prema Mitchell, dok je drugu grupu (Grupa 2) činilo takođe 35 pacijenata, koji su bili lečeni resekcionom artroplastikom, prema Kelleru. Radiografska ispitivanja (Metoda po Hardy I Clapham, Piggott klasifikacija, prisustvo ili odsustvo sekundarnog artiritisa I reaktivnih promena na zglobu prvog metatarzalnog zgloba) su bili analizirani komparativno tokom evaluacije. Analize radiografskih rezultata su učinjene preoperativno i postoperativno za obe grupe.

Rezultati: Prema polu, bilo je 5 muškaraca i 65 žena. Prosečni uzrast pacijenata u Grupi 1 bio je 42 godine, dok je u Grupi 2 bio 56 godina. Nije bilo statistički značajne razlike $(\mathrm{p}<0,05)$ između pacijenata ove dve grupe kada je u pitanju preoperiativna srednja

\section{REFERENCES}

1. Perera AM, Mason L, Stephens MM. The Pathogenesis of hallux valgus. J Bone Joint Surg Am. 2011; 93(17): 1650-61.

2. Nix SE, Vicenzino BT, Collins Nj, Smith MD. Characteristics of foot structure and footwear associated with hallux valgus: a systematic review. Osteoarthritis Cartilage. 2012; 20(10): 1059-74.

3. Nery C, Coughlin MJ, Baumfeld D, Ballerini FJ, Kobata S. Hallux valgus in males - part 2: radiographic assessment of surgical treatment. Foot Ankle Int. 2013; 34(5): 636-44.

4. Nery C, Coughlin MJ, Baumfeld D, Ballerini FJ, Kobata $\mathrm{S}$. Hallux valgus in males -part 1: demographics, etiology, and comparative radiology. Foot Ankle Int. 2013; 34(5): 629-35.

5. Aster AS, Forster MC, Rajan RA, Patel KJ, Asirvatham $\mathrm{R}$, Gillies C. Radiographic pre-operative assessment in hallux valgus: is it reliable? The Foot. 2004; 14(3): 129-32.

6. Berquist TH. Radiology of the Foot and Ankle. 2nd ed. Philadelphia; London: Lippincott Williams \& Wilkins, 2000.

7. Iselin LD, Munt J, Symeonidis PD, Klammer G, Chehade M, Stavrou P. Operative management of common forefoot deformities: a representative survey of Australian orthopaedic surgeons. Foot Ankle Spec. 2012; 5(3): 188-94.

8. Joseph TN, Mroczek KJ. Decision making in the treatment of hallux valgus. Bull NYU Hosp Jt Dis. 2007; 65(1): 19-23.

9. Kitson K. Bunions: their origin and treatment. J Perioper Pract. 2007; 17(7): 308-15.

\section{Correspondence to/Autor za korespondenciju}

Ass. Prof. dr sci. Daniela Georgieva

PHI University Clinic for Orthopedic Surgery,

Bul. "Majka Teresa" bb,

1000, Skopje,

Republic of Macedonia.

e-mail: deni.georgieva@yahoo.com

tel: +38970265513 vrednost dimenzija I metatarzofalangealnog ugla i I intermetatarzalnog ugla. Međutim, radiografska analiza istog ugla u obe grupe, godinu dana posle operacije, pokazala je značajnu razliku $(\mathrm{p}<0,001)$. Pacijenti operisani po Mitchell zahvatu, po Piggott klasifikaciji, su imali devijaciju prvog metatarzalnog zgloba u 51,43\% slučajeva, kao rezultat njihovog hallux valgus deformiteta. Značajno češće se javlja subluksacija na I metatarzofalangealnom zglobu u pacijenata lečenih po Kellerovoj tehnici $(77,14 \%)$. Radiografska analizana I metatarzofalangealnog zgloba (prisustvo ili odsustvo sekundarnih artitisnih ili reaktivnih promena) u obe grupe, preoperativno $(\mathrm{p} 0,01)$ i godinu dana posleo peracije (p 0,001), pokazala je statistički visoku razliku.

Zaključak: Radiografske analize su od značajnog benefita u odlučivanju vrste operacione procedure i za evaluaciju postoperativnih rezultata.

Ključne reči: radiografska analiza, Mitchell, Keller, hallux valgus.

10. Chong A, Nazarian N, Chandrananth J, Tacey M, Shepherd D, Tran P. Surgery for the correction of hallux valgus: Minimum five-year results with a validated patient-reported outcome tool and regression analysis. Bone Joint J.2015; 97-B(2): 208-14.

11. Spruce MC, Bowling FL, Metcalfe SA. A longitudinal study of hallux valgus surgical outcomes using a validated patient centred outcome measure. Foot (Edinb). 2011; 21(3): 133-7.

12. Srivastava S, Chockalingam N, Fakhri T. Radiographic measurements of hallux angles: a review of current techniques. The Foot. 2010; 20(1): 27-31.

13. Kalender AM, Uslu M, Bakan B, et al. Mitchell's osteotomy with mini-plate and screw fixation for hallux valgus. Foot Ankle Int. 2013; 34(2): 238-43.

14. Srivastava S, Chockalingam N, El Fakhri T. Radiographic angles in hallux valgus: comparison between manual and computer-assisted measurements. J Foot Ankle Surg. 2010; 49(6): 523-8.

15. Ferrari J. Bunions. BMJ ClinEvid. 2009.

16. Panchbhavi VK, Rapley J, Trevino SG. First web space soft tissue release in bunion surgery: functional outcomes of a new technique. Foot Ankle Int. 2011; 32(3): 257-61.

17. Easley ME, Trnka HJ.Current concepts review: hallux valgus part II: operative treatment. Foot Ankle Int. 2007; 28(6): $748-58$.

18. Gadek A, Walczak J, Wiecek R, Grzenia G. Kramer's and Keller's methods in hallux valgus deformation treatment. Przegl Lek. 2007; 64(1): 15-8. 